\title{
Modeling the dynamic operation of a small fin plate heat exchanger - parametric analysis
}

\author{
KONRAD MOTYLIŃSKI ${ }^{1}$ \\ JAKUB KUPECKI
}

Thermal Processes Department, Institute of Power Engineering, Augustowka 36, 02-981 Warsaw, Poland

\begin{abstract}
Given its high efficiency, low emissions and multiple fuelling options, the solid oxide fuel cells (SOFC) offer a promising alternative for stationary power generators, especially while engaged in micro-combined heat and power $(\mu$-CHP) units. Despite the fact that the fuel cells are a key component in such power systems, other auxiliaries of the system can play a critical role and therefore require a significant attention. Since SOFC uses a ceramic material as an electrolyte, the high operating temperature (typically of the order of $700-900{ }^{\circ} \mathrm{C}$ ) is required to achieve sufficient performance. For that reason both the fuel and the oxidant have to be preheated before entering the SOFC stack. Hot gases exiting the fuel cell stack transport substantial amount of energy which has to be partly recovered for preheating streams entering the stack and for heating purposes. Effective thermal integration of the $\mu$-CHP can be achieved only when proper technical measures are used. The ability of efficiently preheating the streams of oxidant and fuel relies on heat exchangers which are present in all possible configurations of power system with solid oxide fuel cells. In this work a compact, fin plate heat exchanger operating in the high temperature regime was under consideration. Dynamic model was proposed for investigation of its performance under the transitional states of the fuel cell system. Heat exchanger was simulated using commercial modeling software. The model includes key geometrical and functional parameters. The working conditions of the power unit with SOFC vary due to the several factors, such as load changes, heating and cooling procedures of the stack and others. These issues affect parameters of the incoming streams to the heat exchanger. The mathematical model of the heat exchanger is based on
\end{abstract}

\footnotetext{
${ }^{1}$ Corresponding Author. E-mail: konrad.motylinski@ien.com.pl
} 
a set of equations which are simultaneously solved in the iterative process. It enables to define conditions in the outlets of both the hot and the cold sides. Additionally, model can be used for simulating the stand-alone heat exchanger or for investigations of a semiadiabatic unit located in the hotbox of the $\mu$-CHP unit.

Keywords: Fin plate heat exchanger; Modeling; Dynamic operation; Heat transfer

\section{Introduction}

One of the main reasons of the high cost of delivering electricity to endusers is a strong dependence on energy systems, which operate mostly on fossil fuels as a large stationary plants and require transition of power with proper conditioning systems. Additionally, combustion of fossil fuels results in increased greenhouse gases emissions and other pollutants, which are subject to European Union climate policies. The use of highly efficient and eco-friendly power generation technologies, such as high temperature fuel cells, is a widely developing solution that helps in minimizing the negative impacts of conventional power systems. Micro-combined heat and power ( $\mu$-CHP) systems, producing both heat and electricity in cogeneration, provide potential reductions in carbon emissions and costs through the efficient utilization of fuel and elimination of the use of centrally generated electricity from the grid. A significant benefit of the $\mu$-CHP is its overall efficiency, which can reach $85-90 \%$ [1,2], and operation with clean, alternative fuels [3-5]. The core part of a CHP system is a primary unit, which can be an engine, microturbine or solid oxide fuel cells, which additionally produces waste heat. Heat can be used for the heating purposes or for preparation of the hot utility water $[2,6]$. Moreover, $\mu$-CHP units with solid oxide fuel (SOFC) demonstrate electrical efficiency exceeding $45 \%$ at a power output of single kilowatts [7].

Solid oxide fuel cells are considered prime candidates for stationary power generation in the intermediate to long-term future. Thermal management of the solid oxide fuel cell system is essential not only to prevent the degradation and damage of the fuel cell stack leading to maximization of the cell life, but also to improve its efficiency and performance [8]. The high performance of the SOFC stack depends on several parameters including the in-stack core temperature distribution during steady-state operation and in transitional states. For that reason both fuel and oxidant have to be preheated before entering the SOFC module. This is done according to the 
technical and operational requirements of the particular fuel cell stack [9].

For that reason, heat exchangers which are present in $\mu$-CHP systems with solid oxide fuel cells have to be carefully designed and/or selected to assure proper temperature of the incoming and exiting streams. Fin plate heat exchangers which are considered in the paper, met the given requirements of such power systems. Additionally they are also employed in a wide variety of other applications such as air-conditioning, heat pumping, and refrigeration systems, and play a vital role in terms of manufacturing cost and energy consumption of these systems [10].

In this paper, a dynamic model was proposed for investigation of the performance of a heat exchanger under transitional states. Additionally, the sensitivity of selected parameters to the change of geometrical parameters was investigated. Heat exchanger geometrical and material properties were based on parameters of a device produced by Catacel Corp. [11]. The Heat Exchanger Platform (HEP $\left.{ }^{\circledR}\right)$ is a compact, light-weight and hightemperature heat exchanger. The main parameters of the unit are:

- possibility to operate either in coflow or counterflow configuration,

- light construction and compact size,

- possibility to connect several heat exchangers in series, in parallel or in a combined configuration,

- high effectiveness in a wide range of temperatures,

- capability to configure for operation at pressures up to $0.45 \mathrm{MPa}$,

- possibility to serve as a steam reformer by implementing suitable catalyst coating on the plates installed inside the heat exchanger.

A variety of corrugation geometries can be inserted into the heat exchanger to tailor heat transfer and pressure drop characteristics to the specific needs without significant and costly custom engineering. Catalytic coatings can be applied to the inserts to enable the operation as a reactor as well as a heat exchanger. The available corrugation plates are shown in Fig. 1. The details of these plates are presented further in the paper.

\section{Theory}

The dynamic simulator of a heat exchanger is based on a previously developed stationary model [11]. The original mathematical description was 


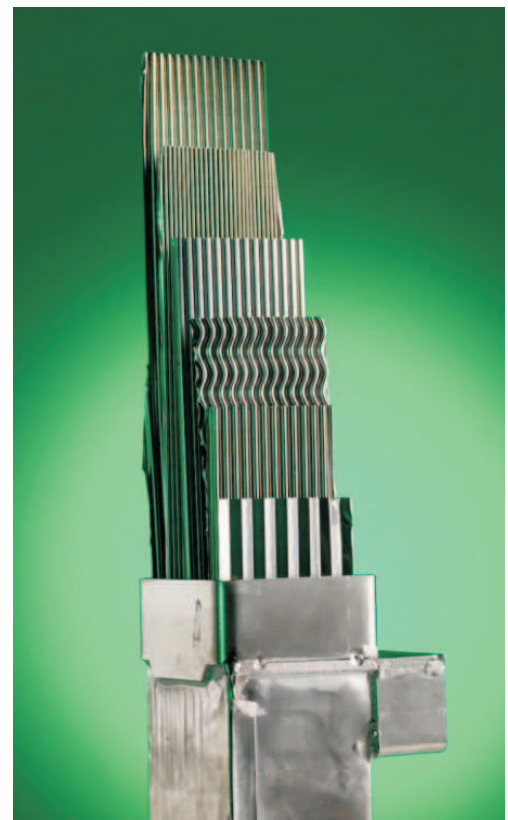

Figure 1: Catacel Heat Exchanger Platform with different plates, Source: Catacel.

used for simulations of an adiabatic heat exchanger operating in a hot box as a part of a $\mu$-CHP power unit with SOFC. In order to simulate the transitional states, a nonadiabatic module was proposed and several additional functionalities were introduced. The pressure drop equations for a compact heat exchanger with corrugated plates were adopted [12]. All calculations were performed iteratively and separately for the hot and cold sides. Such methodology allows to determine the effectiveness of a single fin, hot and cold sides, and the entire heat exchanger. The material properties and geometrical parameters of the heat exchanger are based on the manufacturer's data. The complete set of equations describing the mass and energy transfer are presented in [11].

One of the main parameters necessary to define the performance of the units is the overall effectiveness, $\varepsilon$. The effectiveness is computed iteratively according to

$$
\varepsilon=\frac{1-\exp \left[-N T U\left(1-C_{r}\right)\right]}{1-C_{r} \exp \left[-N T U\left(1-C_{r}\right)\right]},
$$

where heat capacity rate $-C_{r}$ and number of transfer units $-N T U$ are coefficients used in the number of transfer units methodology. Later used 
to determine the outlet temperatures for gases in both sides of the heat exchanger Eq. (2). In the first iteration the initial value of the effectiveness is assumed $\varepsilon_{0}$.

$$
\varepsilon_{0}=\frac{T_{H_{i n}}-T_{H_{\text {out }}}}{T_{H_{\text {in }}}-T_{C_{\text {in }}}}
$$

where $T_{H_{\text {in }}}, T_{H_{\text {out }}}, T_{C_{\text {in }}}$ are the hot side inlet temperature, hot side outlet temperature, and cold side inlet temperature, respectively.

Based on the computed outlet temperatures the effectiveness is found and used as an initial value in the next iteration. Calculation procedure continues until satisfactory convergence is achieved.

Specific heat capacities used in the model are found for the average temperatures computed as an arithmetic mean value of the inlet and outlet temperatures. For proposed methodology [11], one of the many parameters used in determining the performance of the fin plate heat exchanger with different plates are friction factor coefficient, $F F C_{c}$, friction factor exponents, $F F C_{e}$, curve fit coefficients, $C F C$, and curve fit exponents, $C F E$. Values of these parameters are determined by fitting the heat exchanger performance curve to theoretical curves presented in diagram of friction factor for different pipe flows under variable flow conditions (so-called Moody diagrams). This comparison is performed for heat exchanger with different plate types, independently. As a result, configuration with various fin plates generates different values of these parameters for each plate setup.

In order to evaluate the heat exchange process, main dimensionless numbers have to be determined. Reynolds, Stanton, Prandtl and Nusselt numbers have been defined in the form presented below:

$$
\begin{gathered}
\mathrm{Re}=\frac{\bar{\rho} \bar{V} D_{h}}{\bar{\mu}}, \\
\mathrm{St}=\frac{j}{\operatorname{Pr}^{\frac{2}{3}}}, \\
\mathrm{Pr}=\frac{C_{p} \bar{\mu}}{k}, \\
\mathrm{Nu}=\mathrm{StRePr},
\end{gathered}
$$

where, $\bar{\rho}$ is an average density, $\bar{V}$ - average velocity, ${ }^{-}$- average viscosity of the gas, $D_{h}$ - hydraulic diameter, $C_{p}$ specific heat capacity for the average temperature and $k$ is a thermal conductivity coefficient of the installed fin plates. The Colburn factor, $j$, which can be calculated as

$$
j=C F C \operatorname{Re}^{C F E} .
$$


Curve fit coefficient $C F C$ and curve fit exponent $C F E$ are determined for different fin plate types independently. Based on the Nusselt's number, average thermal conductivity of gas, and hydraulic diameter, the heat convection coefficient $h$ can be computed

$$
h=\frac{\mathrm{Nu} k}{D_{h}} .
$$

Heat convection coefficient is one of the elements needed for determination of single fin surface heat exchange effectiveness, which is needed for evaluation of overall heat exchange process.

The heat exchanger effectiveness is also correlated with the total amount of heat exchanged between both sides, $Q_{\max }$, pressure losses, $p_{\text {total }}$, and thermal resistances, $R_{t h_{t o t}}$. The theory and detailed discussion of these equations is given elsewhere [11].

$$
\begin{aligned}
& Q_{\max }=\left[M I N\left(m_{H} C_{p H}, m_{C} C_{p C}\right)\right] \cdot\left(T_{H_{\text {in }}}-T_{C_{\text {in }}}\right), \\
& \triangle p_{\text {total }}=\Delta p_{\text {entrance }}+\triangle p_{\text {acceleration }}+\triangle p_{\text {exit }}+\triangle p_{\text {core_friction }}, \\
& R_{t h_{t o t}}=R_{t h_{h s-w}}+R_{t h_{w}}+R_{t h_{c s-w}} .
\end{aligned}
$$

where: $m_{H}$ - hot side gas mass flow, $m_{C}$ - cold side gas mass flow, $C_{p H}$ - hot side gas heat capacity, $C_{p C}$ - cold side gas heat capacity, $\Delta p_{\text {entrance }}$ - pressure drop due to the entrance effect, $\Delta p_{\text {acceleration }}$ - pressure drop due to the fluid acceleration, $p_{\text {exit }}$ - pressure drop due to the exit effect, $p_{\text {core_friction }}$ - pressure drop due to the core friction, $R_{t h_{h s-w}}$ - thermal resistance between hot stream and wall, $R_{t h_{w}}$ - thermal resistance of the wall, $R_{t h_{c s-w}}$ - thermal resistance between cold stream and wall. The method allows to evaluate the effectiveness of a heat exchanger, including the geometrical parameters of the hot and the cold side, properties of the working fluids and the corresponding molar flows. These parameters can be adjusted to enable simulation of heat exchangers with a modified geometry, and under off-design working conditions.

\section{Dynamic model}

The heat exchanger was modelled using simulator implemented in commercial Aspen Hysys 8.5 modeling software [15]. In order to predict the behaviour of a compact fin plate heat exchanger during the dynamic states, 
Table 1: Boundary conditions.

\begin{tabular}{|c|c|}
\hline Parameters and units & Values \\
\hline \multicolumn{2}{|l|}{ Non-adiabatic model } \\
\hline Ambient temperature $\left[{ }^{\circ} \mathrm{C}\right]$ & 25 \\
\hline \multicolumn{2}{|l|}{ Heat exchanger wall material } \\
\hline \multicolumn{2}{|l|}{ Stainless steel } \\
\hline Thermal conductivity $\left[\mathrm{Wm}^{-1} \mathrm{~K}^{-1}\right]$ & $14.85-25$ at $20-800^{\circ} \mathrm{C}$ \\
\hline Heat capacity $\left[\mathrm{kJkg}^{\left.-1{ }^{\circ} \mathrm{C}^{-1}\right]}\right.$ & $0.4555-0.5564$ at $20-800^{\circ} \mathrm{C}$ \\
\hline \multicolumn{2}{|l|}{ Insulation } \\
\hline \multicolumn{2}{|l|}{ Porous insulation } \\
\hline Thickness [mm] & $\begin{array}{l}25 \\
0.065 \text { at } 50^{\circ} \mathrm{C} \\
0.079 \text { at } 200^{\circ} \mathrm{C}\end{array}$ \\
\hline Thermal conductivity $\left[\mathrm{Wm}^{-1} \mathrm{~K}^{-1}\right]$ & $\begin{array}{l}0.103 \text { at } 400^{\circ} \mathrm{C} \\
0.173 \text { at } 800^{\circ} \mathrm{C} \\
\text { (interpolation done for other } \\
\text { temperatures) }\end{array}$ \\
\hline Heat capacity $\left[\mathrm{kJkg}^{\left.-1{ }^{\circ} \mathrm{C}^{-1}\right]}\right.$ & 1.03 \\
\hline $\begin{array}{l}\text { Inner gas - heat exchanger wall heat transfer coefficient } \\
{\left[\mathrm{Wm}^{-2}{ }^{\circ} \mathrm{C}^{-1}\right]}\end{array}$ & 50 \\
\hline $\begin{array}{l}\text { Heat exchanger wall - atmosphere heat transfer coef- } \\
\text { ficient }\left[\mathrm{Wm}^{-2}{ }^{\circ} \mathrm{C}^{-1}\right]\end{array}$ & 20 \\
\hline Mass of the heat exchanger $[\mathrm{kg}]$ & 0.4 \\
\hline \multicolumn{2}{|l|}{$\begin{array}{l}\text { Geometric parameters of the heat exchanger are based } \\
\text { on the data from the manufacturer }\end{array}$} \\
\hline $\begin{array}{l}\text { Model of the working media described by the Peng- } \\
\text {-Robinson equation of state }\end{array}$ & \\
\hline
\end{tabular}

additional modules accounting for the nonadiabatic effects were proposed. The boundary conditions of the dynamic model are presented in Tab. 1.

The dynamic HTX model comprises of three different parts: (I) adiabatic module, (II) non-adiabatic module and (III) the control panel. The adiabatic module includes equations and assumptions described earlier. The non-adiabatic module makes it possible to calculate thermal losses from the heat exchanger through the walls and insulation to the surrounding. Based on the assumptions and the inlet values, simulator calculates the total heat transfer between heat exchanger and the ambient. Results are then exported to the adiabatic module, where the core calculations are performed. The third part includes proportional-integral (PI) controlling objects. There are 
nine PI controllers in total, which are responsible for the key parameters, for the hot and cold side of the heat exchanger. The PI objects regulate fluids flows, pressure and temperature. For each PI used in the simulator, a specific setting values were proposed, based on earlier reported data [13], and are a result of manual tuning. The PI settings are presented in Tab. 2.

Table 2: Setting of PI controllers in the simulator.

\begin{tabular}{|c|c|c|l|}
\hline PI number & $\mathrm{K}$ & $\mathrm{Ti}[\mathrm{min}]$ & \multicolumn{1}{c|}{ Main role } \\
\hline \hline 1 & 0.1 & 0.1 & controls iterative calculations \\
\hline 2 & 0.005 & 0.2 & setting inlet gas flow in the hot side \\
\hline 3 & 0.005 & 0.2 & setting inlet gas flow in the cold side \\
\hline 4 & 0.01 & 0.1 & setting inlet gas pressure in the hot side \\
\hline 5 & 0.01 & 0.1 & setting inlet gas pressure in the cold side \\
\hline 6 & 0.2 & 0.2 & setting inlet gas temperature in the hot side \\
\hline 7 & 0.2 & 0.2 & setting inlet gas temperature in the cold side \\
\hline 8 & 0.2 & 0.2 & setting outlet gas pressure in the hot side \\
\hline 9 & 0.2 & 0.2 & setting outlet gas pressure in the cold side \\
\hline
\end{tabular}

where: $\mathrm{K}$ - proportional gain coefficient, $\mathrm{Ti}$ - integral gain coefficient.

\section{Simulations and results}

The dynamic model makes it possible to simulate alternative scenarios, determine the outlet parameters of the heat exchanger in transitional states. Additionally it enables modification of all geometrical parameters corresponding to the modified design of a unit.

Simulations presented in the papers were done to investigate the sensitivity of the performance of a heat exchanger to change the selected geometrical parameters. Numerical calculations were not followed by experimental evaluations. For that reason the results should be considered purely theoretical. Such approach was however accepted due to the use of the well-validated stationary model which was adjusted for dynamic calculations. Proper adaptation of the parameters of a heat exchanger operating in the high temperature regime enables to increase the thermal integration of a power system by improved thermal management of the incoming and exiting streams. Additionally, reduction of the pressure losses and the corresponding power of blowers, allows to elevate the efficiency by reduction 
of the auxiliary power consumptions. For that purpose it was important to perform parametric sensitivity analysis and indicate the potential directions for improvement of the design of heat exchangers.

Simulations done using the dynamic tools were focused on comparison of the performance in alternative configurations of the flow channels inside the heat exchanger. The considered options included different inner plates: (I) plain flat crest (Fig. 2), (II) ruffled (Fig. 3), (III) corrugated (Fig. 4), and (IV) plain round crest (Fig. 5).

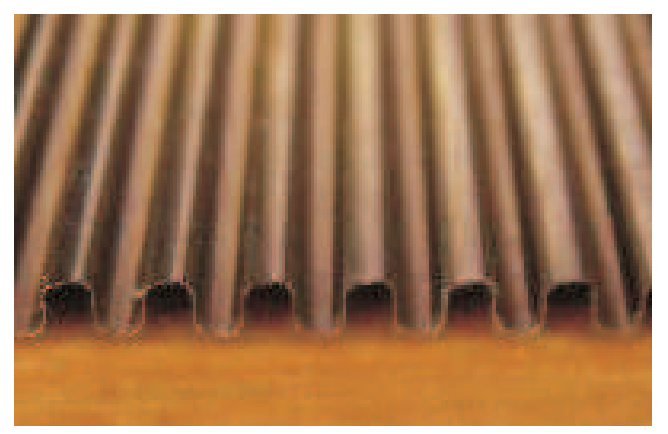

Figure 2: Catacel plate type - plain flat crest [16].

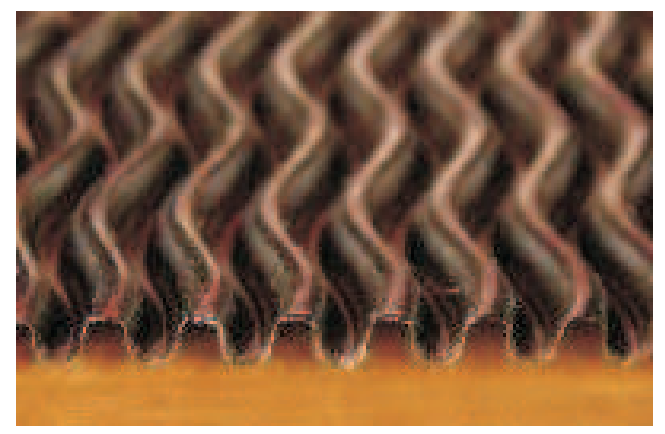

Figure 3: Catacel plate type - ruffled [16].

Each plate is made of the same material type - fecralloy, with assumed, constant thermal conductivity $16\left[\mathrm{Wm}^{-1} \mathrm{~K}^{-1}\right]$ The geometry of each plate is defined by certain values of the parameters such as corrugation length, masked length and fin length. The influence of these parameters on the heat exchanger performance is discussed further in this paper. The friction factor and curve fit coefficients and exponents were also included in the data re- 


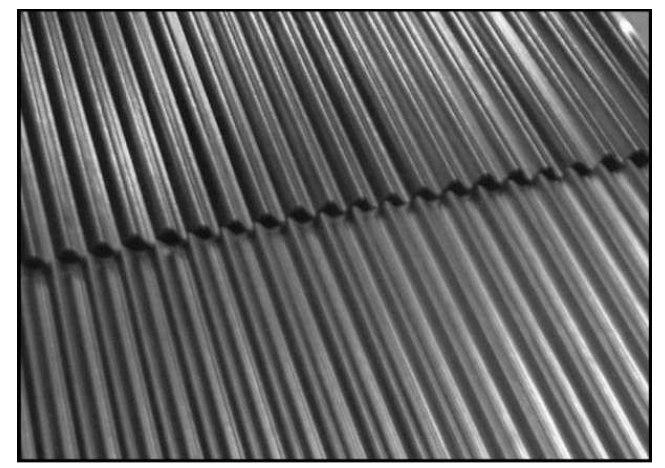

Figure 4: Catacel plate type - corrugated [16] .

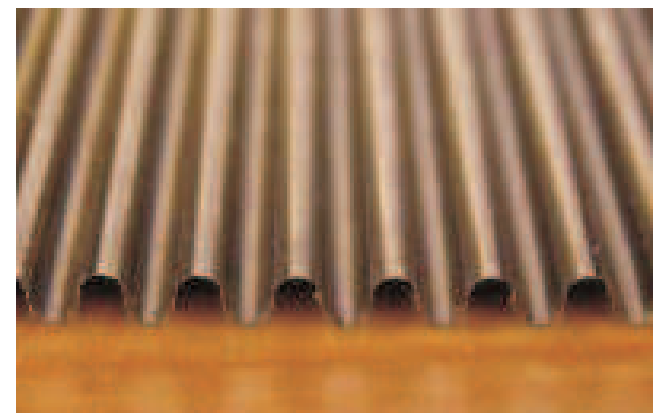

Figure 5: Catacel plate type - plain round crest [16]

ceived from the heat exchanger manufacturer, for each plate independently. Each of these parameters have an influence on the heat exchanger effectiveness, thus on the overall performance.

The dynamic model allows to perform simulations for cocurrent and countercurrent flow configurations. Currently both options were considered. In order to investigate the operation of the heat exchanger during transients, the model was used for set of alternative operating scenarios. Calculations were performed for the co- and countercurrent flow arrangements. In the computational algorithm the only difference between the co-current and the counter-current flow configuration is the form of Eq. (1) describing the overall effectiveness of the heat exchanger. Proper rearrangement has to be done to enable determination of the effectiveness in either options. Equation (1) correspond to the countercurrent setup. For cocurrent flow the following 
equation have been used:

$$
\varepsilon=\frac{1-\exp \left[-N T U\left(1+C_{r}\right)\right]}{1+C_{r}} .
$$

The first simulation was focused on evaluation of the time required to reach the steady-state condition in the outlets of the heat exchanger. The initial boundary conditions of the simulation are presented in Tab. 2, and the parameters of the inlet gas are summarized in Tab. 3 .

Table 3: Initial boundary conditions.

\begin{tabular}{|l|l|}
\hline \multicolumn{1}{|c|}{ Parameters } & $\begin{array}{l}\text { Values and } \\
\text { comments }\end{array}$ \\
\hline \hline $\begin{array}{l}\text { Inlet gases temperature at the start } \\
\text { of the simulation }\end{array}$ & Ambient \\
\hline $\begin{array}{l}\text { Heat exchanger materials tempera- } \\
\text { ture at the start of the simulation }\end{array}$ & Ambient \\
\hline Outlet pressure in both sides $[\mathrm{MPa}]$ & 0.1 \\
\hline
\end{tabular}

Table 4: Inlet parameters for the simulation.

\begin{tabular}{|l|c|c|}
\hline \multicolumn{1}{|c|}{ Inlet parameters } & Hot side & Cold side \\
\hline \hline Temperature $\left[{ }^{\circ} \mathrm{C}\right]$ & 750 & 250 \\
\hline Flow $\left[\mathrm{Nm}^{3} \mathrm{~h}^{-1}\right]$ & 15.5 & 15.5 \\
\hline Composition & $21 \% \mathrm{O}_{2}, 79 \% \mathrm{~N}_{2}$ & $21 \% \mathrm{O}_{2}, 79 \% \mathrm{~N}_{2}$ \\
\hline
\end{tabular}

In the initial phase, the heat exchanger is in a cold state and no gases are directed to the unit. After the gases begin entering both sides of the heat exchanger the outlet temperature rises, reaching the steady-state after several minutes. Data obtained from the model for four different plates and flow configurations are presented in Figs. 6 and 7. Numbers 1-4 presented in the charts represent: plain flat crest, ruffled, corrugated and plain round crest, respectively. The HS_out and CS_out correspond to the outlets of the hot and the cold sides, respectively. As can be observed in Figs. 6 and 7 required stabilization time is identical. The final results after achieving steady-state for each simulation are shown in Tabs. 5 and 6 .

In Fig. 6 it can be observed that in the countercurrent flow configuration use of different plates leads to visible effects on the performance of the 


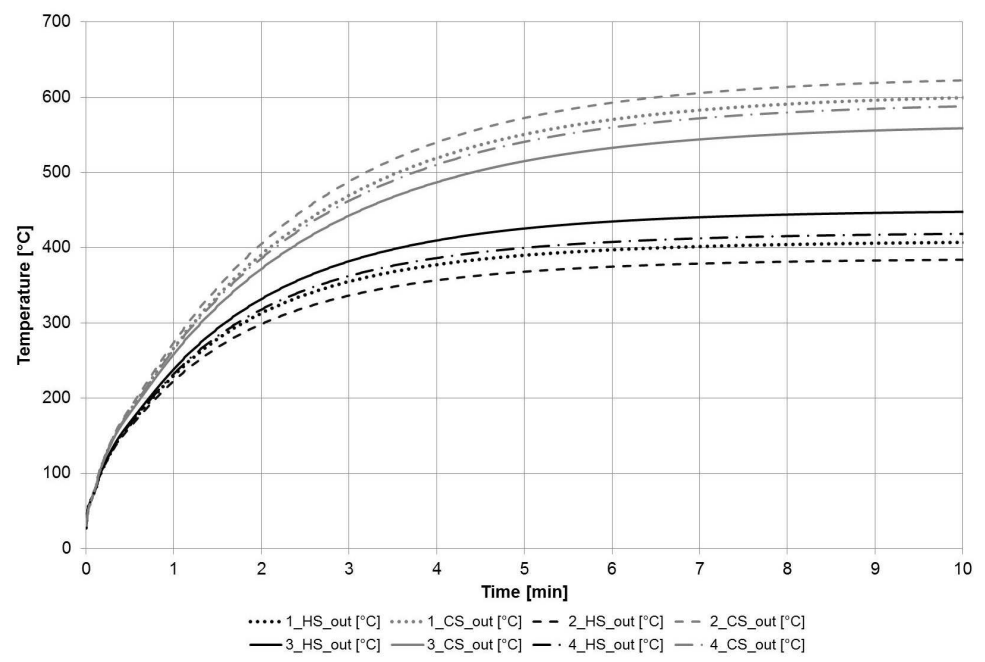

Figure 6: Heat exchanger outlet temperature after reaching steady-state at countercurrent flow.

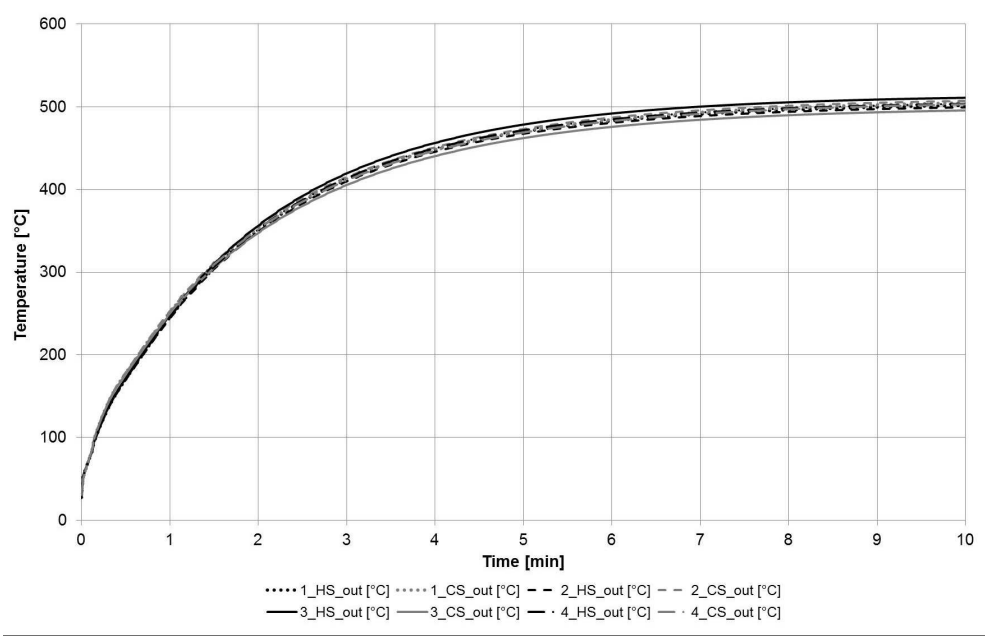

Figure 7: Heat exchanger outlet temperature after reaching steady-state at co-current flow.

heat exchanger. In the given working conditions the lowest effectiveness is obtained for the corrugated plates, while the highest values are achieved for the ruffled plates. Results obtained from the model indicate that different plates used in the countercurrent configuration lead to significant variations 
Table 5: Final results obtained from the simulation after reaching steady-state conditions for the countercurrent flow.

\begin{tabular}{|l|c|c|c|c|c|}
\hline Plate form & $\begin{array}{c}\text { HS outlet } \\
\text { temperature } \\
{\left[{ }^{\circ} \mathrm{C}\right]}\end{array}$ & $\begin{array}{c}\text { CS outlet } \\
\text { temperature } \\
{\left[{ }^{\circ} \mathrm{C}\right]}\end{array}$ & $\begin{array}{c}\text { HS pres- } \\
\text { sure drop } \\
{[\mathrm{Pa}]}\end{array}$ & $\begin{array}{c}\text { CS pressure } \\
\text { drop } \\
{[\mathrm{Pa}]}\end{array}$ & $\begin{array}{c}\text { Effectiveness } \\
{[\%]}\end{array}$ \\
\hline \hline Plain flat crest & 409.04 & 605.56 & 5512 & 4075 & 69.09 \\
\hline Ruffled & 385.86 & 628.74 & 7312 & 5802 & 73.60 \\
\hline Corrugated & 450.33 & 564.27 & 3723 & 2588 & 61.07 \\
\hline Plain round crest & 420.65 & 593.95 & 4895 & 3512 & 66.84 \\
\hline
\end{tabular}

Table 6: Final results obtained from the simulation after reaching steady-state conditions for the cocurrent flow.

\begin{tabular}{|l|c|c|c|c|c|}
\hline Plate form & $\begin{array}{c}\text { HS outlet } \\
\text { temperature } \\
{\left[{ }^{\circ} \mathrm{C}\right]}\end{array}$ & $\begin{array}{c}\text { CS outlet } \\
\text { temperature } \\
{\left[{ }^{\circ} \mathrm{C}\right]}\end{array}$ & $\begin{array}{c}\text { HS pres- } \\
\text { sure drop } \\
{[\mathrm{Pa}]}\end{array}$ & $\begin{array}{c}\text { CS pressure } \\
\text { drop } \\
{[\mathrm{Pa}]}\end{array}$ & $\begin{array}{c}\text { Effectiveness } \\
{[\%]}\end{array}$ \\
\hline \hline Plain flat crest & 505.59 & 509.01 & 6077 & 3651 & 50.33 \\
\hline Ruffled & 503.22 & 511.38 & 8122 & 5148 & 50.79 \\
\hline Corrugated & 514.82 & 499.78 & 3970 & 2411 & 48.54 \\
\hline Plain round crest & 507.46 & 507.14 & 5358 & 3175 & 49.97 \\
\hline
\end{tabular}

in the outlet temperatures and pressure losses. In the cocurrent flow configuration (Fig. 7) only the pressure drops considerably vary between the different plates. Both the effectiveness and the outlet temperatures reaches similar values in each case. The computed relative difference is equal to $4 \%$. For the given inlet conditions, the corrugated plate leads to the lowest pressure drop.

Steady-state conditions in each simulation were achieved in about $10 \mathrm{~min}$. It can be concluded that alternative configurations in the simulator do not have a significant effect on the time required to reach steady-state conditions in the outlets.

Efficiency-wise, it is essential to select optimal outline of a $\mu$-CHP unit leading to the lowest pressure losses. The reduction of pressure drops results in minimization of the power of compressors and maximization of the electrical and overall system efficiency. A generic $\mu$-CHP unit is equipped with several machines including air blower and the draft fan. For both co- 
and counter-current flow configuration of the heat exchanger, use of corrugated plates leads to the lowest pressure loses. Simulations performed for the corrugated plates indicated that their implementation results also in the lowest effectiveness in both considered flow configurations. Counter-current flow configuration in the analysed scenarios enables achieving higher effectiveness of the heat exchanger and lower pressure drops than cocurrent. For that reason this configuration is more attractive for the $\mu$-CHP systems with solid oxide fuel cells.

Additionally, evaluation of the sensitivity of the heat exchanger performance to changes of selected geometrical parameters was scrutinised. For that purpose the nominal values of the corrugated height, corrugated length, fin length, masked length and foil thickness were modified in the range from $-10 \%$ to $+10 \%$ with $5 \%$ step. This allowed to observe the overall effects of the modification of selected parameters on the performance of the heat exchanger.

Simulations were done for both flow configurations and different plate forms. It was found that the fin length and corrugated height have minor effect on the performance (less than $0.5 \%$ ) and for that reason will not be further considered. Modification of corrugated length, masked length and foil thickness have a visible effect on the heat exchanger operation.

Performed simulations show also that cocurrent flow configuration slightly affects the heat exchanger performance, thus generated results presented in Figs. 8-10 correspond only to countercurrent flow configuration. Based on the results presented in Figs. 8-10, the geometrical parameters with highest impact on the heat exchanger performance are the corrugated length and the masked length. Modifying the structural imperfections from 5\% to 10\% in each cases resulted in linear changes of the outlet parameters. Proposed increase and decrease ranges are unlikely to occur, due to the very precise production process of the plate forms [13]. The only noticeable impacts concern pressure drops on hot and cold side of the heat exchanger. Geometrical parameters of plate forms do not influence the pressure losses by more than $6 \%$. It can be concluded that potential structural inaccuracies will not have any major impact on the overall system performance. 

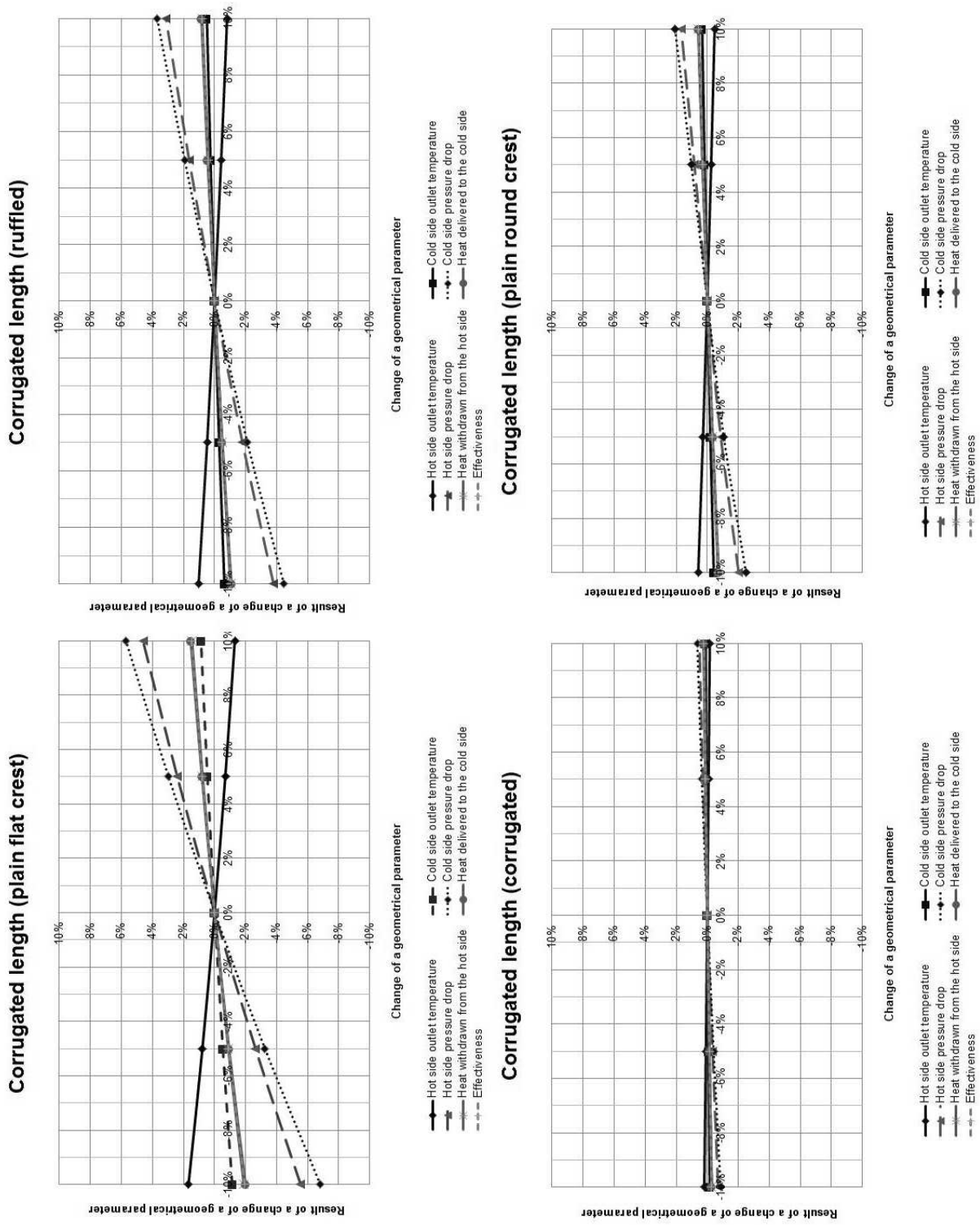

Figure 8: Impact of corrugated length on heat exchanger performance at countercurrent flow. 

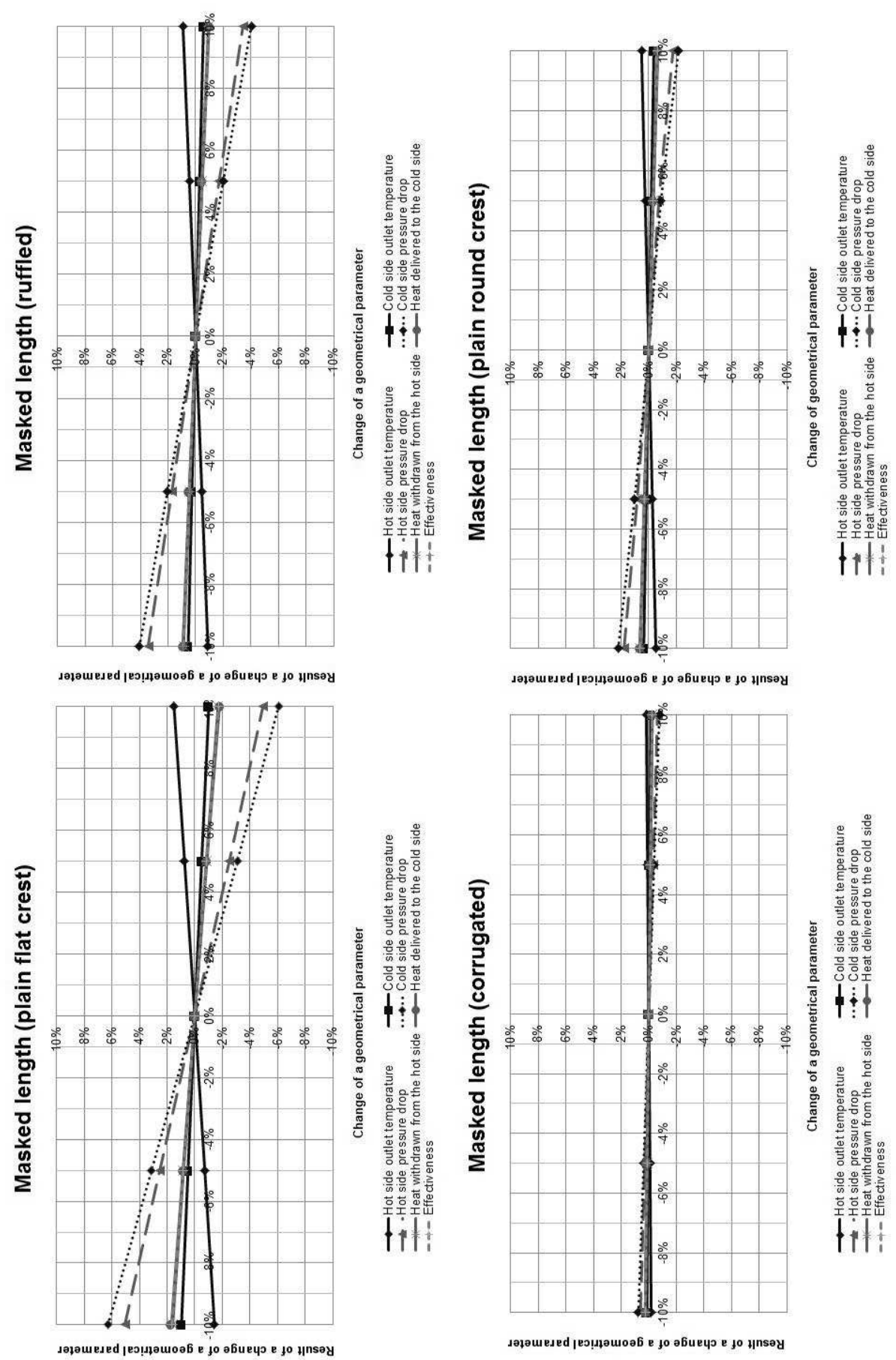

Figure 9: Impact of masked length on heat exchanger performance at countercurrent flow. 

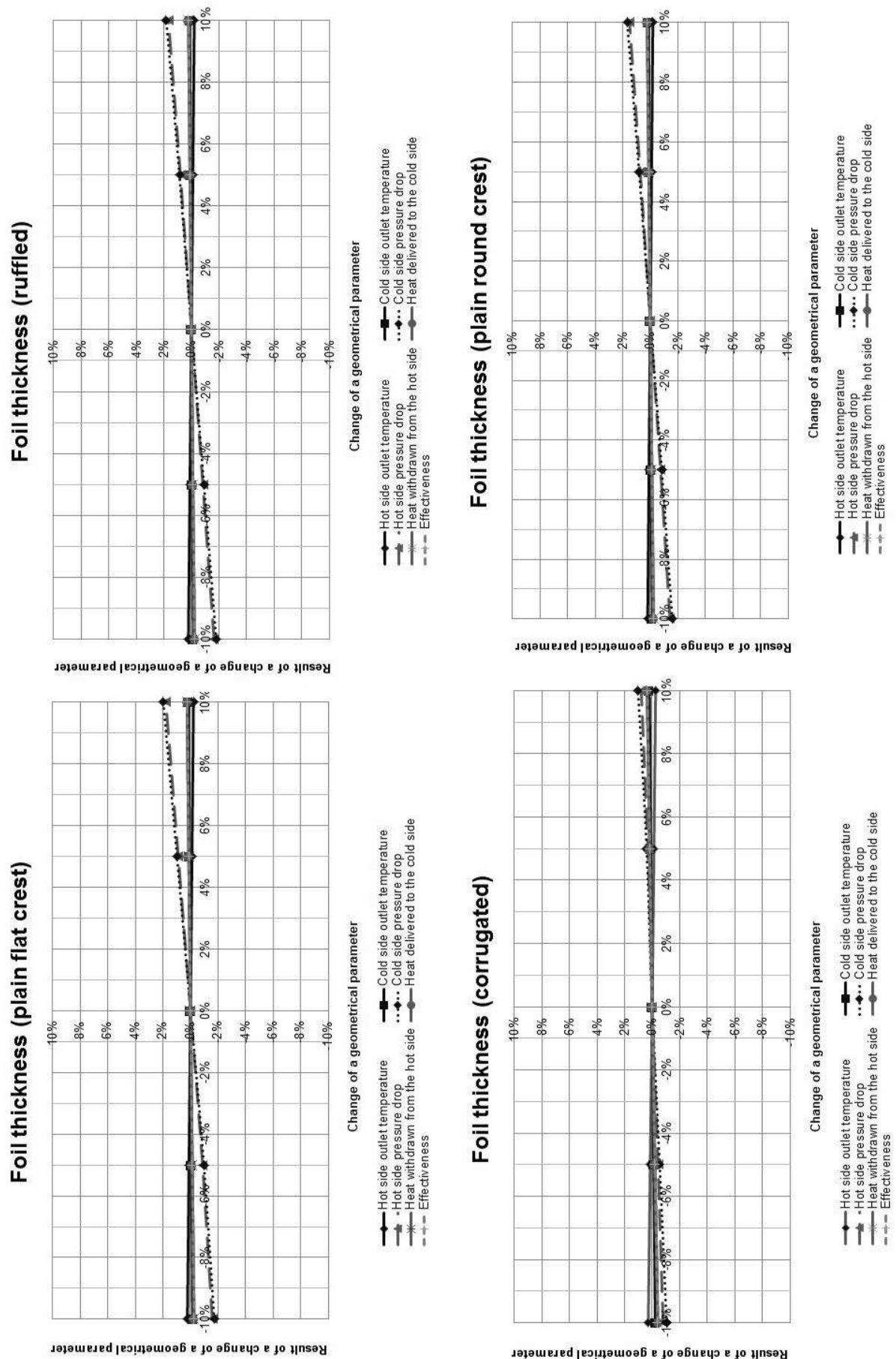

Figure 10: Impact of foil thickness on heat exchanger performance at countercurrent flow. 


\section{Conclusion}

The dynamic model of a small plate fin heat exchanger was constructed and implemented in commercial modeling software. In the first step, the theoretical calculations were performed to analyse the dynamic response during start-up for four optional inner plates. In the second phase, the parametric evaluation was performed. In the study, five parameters were modified in the range $\pm 10 \%$ to observe the effects on the outlet temperature, pressure drops, heat exchanged between the sides and the overall effectiveness of the heat exchanger. Four optional geometries were under consideration and it was found that the corrugate plates are the most insensitive to modification of the geometrical parameters, while the plain flat crest inner exhibit the highest sensitivity.

Results of the study are of high importance for the design, construction and operation of a micro-CHP system with solid oxide fuel cells incorporating heat exchangers of the type discussed in the paper. The current sensitivity analysis was performed for heat exchanger operating with air in both, the hot and cold side. Such reference conditions were chosen to make it possible to observe the overall effects of modifying selected geometrical specifications. In real operation of the heat exchanger in a micro-CHP system with SOFCs, the unit is exposed to substantial variations of both the mass flow and compositions of the gases entering both sides of the heat exchanger. Evaluation of the operation of the heat exchanger can be done only when sufficient experimental data collected during operation of the complete power system are available. In current work it was assumed that the validated stationary model of a heat exchanger can be modified into a dynamic simulator to conduct the study. Future studies will be related to validation of the simulator under real operating conditions.

Acknowledgements The authors would like to gratefully acknowledge the support from the EU through the ONSITE project (grant agreement $325325)$.

Received 9 November 2015

\section{References}

[1] Kaundinya D.P., Balachandra P., Ravindranah N.H.: Grid-connected versus stand-alone energy systems for decentralized power - A review of literature. Re- 
new. Sust. Energ. Rev. 13(2009), 2041-2050.

[2] Frenzel I., Loukou A., Trimis D., Schroeter F., Mir L. et al.: Development of an SOFC based micro-CHP system in the framework of the European project FC-DISTRICT. Energy Procedia 28(2012), 170-181.

[3] Staniforth J., Ormerod R.M.: Running solid oxide fuel cells on biogas. Ionics $\mathbf{9}(2003), 5-6,336-341$.

[4] Wojcik A., Middleton H., Damopoulos I., Van Heerle J.: Ammonia as fuel in solid oxide fuel cells. J. Power Sources 118(2003), 1-2, 342-348.

[5] Murray E., Harris S., Jen H.: Solid oxide fuel cells utilizing dimethyl ether fuel. J. Electrochem. Soc. 149(2002), 9, A1127-A1131.

[6] Machackova A., Kocich R., Bojko M., Kleckova Z.: Numerical analysis of secondary heat exchanger designed for CHP units with microturbine. Int. J. Heat Mass Tran. 83(2015), 487-498.

[7] Kupecki J., Badyda K.: SOFC-based micro-CHP system as an example of efficient power generation unit. Arch. Thermodyn. 32(2011), 3, 33-43.

[8] Vijay P., Hosseini S., Tade M.: A novel concept for improved thermal management of the planar SOFC. Chem. Eng. Res. Design 91(2013), 560-572.

[9] Kupecki J., Milewski J., Szczesniak A., Bernat R., Motylinski K.: Dynamic numerical analysis of cross-, co-, and counter-current flow configurations of a $1 \mathrm{~kW}$-class solid oxide fuel cell stack. Int. J. Hydrogen Energ. 40(2015), 45, 1583415844 .

[10] Korzeń A., Taler D.: Modeling of transient response of a plate fin and tube heat exchanger. Int. J. Therm. Sci. 92(2015), 188-198.

[11] Kupecki J., BAdyda K.: Mathematical model of a plate fin heat exchanger operating under solid oxide fuel cell working conditions. Arch. Thermodyn. 34(2013), 4, $3-21$.

[12] Kays W., London A.: Compact heat exchangers. McGraw-Hill, New York 1958.

[13] Skogestad S.: Probably the best simple PID tuning rules in the world. J. Process Contr. 2001.

[14] Whittenberger W.A.: Custom Solutions for Fuel Cell Applications that are Smaller, Lighter, Less Costly and/or more Efficient. Catalytic Heat-Exchanging Materials Technology. White Paper 101, 2009.

[15] Aspen HYSYS, ver 8.5, Jump Start Guide: Getting Started with Aspen HYSYS V8.5, aspentech, Inc., USA

[16] Product specification - HEP by Catacel, Producerñs data, 2014 